\title{
ANALISIS POTENSI PETERNAK DALAM PENGEMBANGAN SAPI BALI DI KECAMATAN TANIWEL KABUPATEN SERAM BAGIAN BARAT
}

\author{
Pieter M. Ririmasse* \\ Jurusan Peternakan, Fakultas Pertanian, Universitas Pattimura \\ Jl. Ir.M. Putuhena, Kampus Poka, Ambon 97233 \\ *Email : pieter.ririmasse@ faperta.unpatti.ac.id
}

\begin{abstract}
ABSTRAK
Sumber daya alam, sumber daya pakan ternak yang berkesinambungan, dan sumber daya manusia merupakan faktor-faktor yang perlu diperhatikan dalam melaksanakan pengembangan sapi potong seperti halnya sapi Bali. Sebagai suatu kegiatan produksi yang berorientasi ekonomi, kinerja usaha peternakan dengan pendekatan kawasan sangat ditentukan oleh peran peternak sebagai pelaku utamanya baik secara individu maupun secara kelompok. Penelitian ini bertujuan untuk mengkaji dan mengetahui potensi individu peternak dalam pengembangan sapi Bali di Kecamatan Taniwel. Dalam penelitian ditetapkan 3 desa sampel secara Purposive Sampling sedangkan total responden yang dipilih sebanyak 30 peternak yang ditentukan secara purposive sampling. Variabel yang diamati adalah potensi dasar peternak yang meliputi pengalaman beternak, pendidikan (formal dan non formal, kemampuan baca tulis), intensitas berkomunikasi, potensi tenaga kerja peternak, potensi penguasaan teknologi peternak, dan potensi penyediaan input produksi peternak. Data dikumpulkan kemudian ditabulasi dan dianalisis dengan menggunakan menghitung nilai rata-rata dan simpangan baku. Hasil penelitian menunjukkan bahwa skor potensi dasar peternak sebesar 94,16, skor potensi tenaga kerja yang dimiliki peternak yaitu sebesar 6,17 berada pada kategori rendah, potensi penguasaan teknologi yang dimiliki peternak berada pada kategori rendah yakni dengan skor sebesar 4,23, dan skor potensi penyediaan input oleh peternak adalah sebesar 16 berada pada kategori rendah. Dapat disimpulkan bahwa skor akhir potensi peternak dalam pengembangan sapi Bali di Kecamatan Taniwel masuk dalam kategori rendah dengan skor sebesar 409,39.
\end{abstract}

Kata kunci : Potensi dasar, penggunaan teknologi, penyediaan input, peternak, sapi Bali

\section{ANALYSIS OF FARMERS POTENTIAL IN BALI BEEF DEVELOPMENT IN TANIWEL DISTRICT SERAM BARAT REGENCY}

\begin{abstract}
Natural resources, sustainable animal feed resources, and human resources are factors that need to be considered in carrying out the development of beef cattle such as Bali cattle. As an economy-oriented production activity, the performance of livestock business with a regional approach is largely determined by the role of breeders as the main factors, both individually and as a group. This study aims were both to know and determine the potential of individual breeders in Bali cattle development in Taniwel District. In the study, three sample villages were selected using purposive sampling method, while the total respondents selected were 30 breeders who were determined by purposive sampling. The variables observed were the basic potential of the breeders which included breeding experience, education (formal and non-formal, literacy skills), communication intensity, the potential of the breeder workforce, the potential for farmer technology mastery, and the potential for providing input to breeders' production. The data were collected then tabulated and analyzed using the average value and standard deviation. The results showed that the basic potential score of breeders was 94.16, the score for the workforce potential of the breeders was 6.17 in the low category, the potential mastery of technology owned by the breeders was in the low category with a score of 4.23 , and the score The potential for providing input by breeders is 16 in the low category. It can be concluded that the final score of potential breeders in developing Bali cattle in Taniwel District is in the low category with a score of 409.39 .
\end{abstract}

Key words: Basic potential, use of technology, provision of inputs, breeders, Bali cattle 


\section{PENDAHULUAN}

Pengembangan peternakan berperan besar dalam pembangunan pertanian, baik dalam aspek penyediaan pangan, penyerapan tenaga kerja, pengentasan kemiskinan, maupun aspek kelestarian lingkungan hidup. Usaha ternak ruminansia seperti sapi, kerbau, domba dan kambing sudah berada pada usaha yang berorientasi bisnis, sehingga dalam pengembangnya diarahkan kepada peningkatan keuntungan (Ariningsih, 2014). Usaha sapi potong dalam pengembangannya dapat dicapai dengan memanfaatkan sumberdaya secara optimal dan tepat guna yang disesuaikan dengan keadaan alam, kondisi sosial ekonomi masyarakat setempat, sarana prasarana, teknologi peternakan yang berkembang dan kelembagaan serta kebijakan yang mendukung (Prawira dkk., 2015).

Sapi potong lokal, terutama sapi Bali, mempunyai keistimewaan dalam hal daya reproduksi, persentase karkas serta kualitas daging dan kulit, tetapi mempunyai keterbatasan dalam hal kecepatan pertumbuhan dan ukuran bobot badan. Di sisi lain, sapi Bali dapat memanfaatkan pakan lokal yang berkualitas rendah, serta mampu beradaptasi dengan lingkungan lembab tropis dan tahan menghadapi serangan parasit yang merugikan. Sapi Bali sebagai sumberdaya genetik ternak potong asli Indonesia saat ini sangat diminati masyarakat di dalam maupun luar negeri. Sapi Bali memiliki suatu strategi bertahan hidup sesuai dengan kondisi agroekologi dan diduga memiliki sifat elastisitas fenotipik dalam bentuk mampu menyesuaikan kondisi badan dan mempertahankan daya reproduksi yang tinggi (Diwyanto \& Priyanti, 2008).

Usaha peternakan sapi Bali sudah tidak asing lagi bagi masyarakat peternak terutama di kawasan timur Indonesia. Kondisi wilayah yang luas memungkinkan pembentukan dan atau pengembangan suatu kawasan budidaya sapi Bali sebagai sapi potong guna peningkatan ketahanan pangan untuk mewakili kebutuhan masyarakat akan protein hewani, peningkatan pendapatan petani peternak, dan pendapatan asli daerah. Potensi wilayah yang mendukung serta ketersediaan bahan baku pakan dan sumber daya manusia memungkinkan pengembangan sapi potong berbasis sumber daya lokal di wilayah tersebut (Rajab, 2013). Di Kecamatan Taniwel Kabupaten Seram Bagian Barat, usaha peternakan sapi Bali sudah dilakukan sejak lama bahkan oleh sebagian peternak usaha ini sudah dilakukan secara turuntemurun, meskipun jenis usaha peternakan ini masih dijadikan sebagai usaha sampingan sebagai bagian dari usaha tani yang dikelola dengan pola tradisional atau bersifat semi intensif. Berdasarkan data kecamatan, populasi ternak sapi potong yang umumnya merupakan sapi Bali yang ada di Kecamatan Taniwel pada tahun 2017 berjumlah 1.916 ekor (BPS Kabupaten Seram Bagian Barat, 2018).
Sumber daya alam, sumber daya pakan ternak yang berkesinambungan, dan sumber daya manusia merupakan faktor-faktor yang perlu diperhatikan dalam melaksanakan pengembangan sapi potong seperti halnya sapi Bali (Suroso \& Nurhasan, 2014). Sebagai suatu kegiatan produksi yang berorientasi ekonomi, kinerja usaha peternakan dengan pendekatan kawasan sangat ditentukan oleh peran peternak sebagai pelaku utamanya baik secara individu maupun secara kelompok (Arfiani dkk., 2015). Dengan demikian tingkat perkembangan usaha peternakan dalam suatu proses produksi yang dilakukan oleh peternak, peran peternak yang optimal ditentukan oleh potensi internal peternak, dan juga pengaruh eksternal dimana peternak tersebut berada (Sodiq, 2011 ; Listiana, 2010). Potensi dasar yang dimiliki peternak menunjukkan kemampuan peternak mengembangkan usaha ternaknya di suatu kawasan. Potensi dasar peternak diantaranya pengalaman beternak, tingkat pendidikan formal dan non formal, serta intensitas berkomunikasi peternak (Suroso \& Nurhasan, 2014). Penelitian ini bertujuan untuk mengkaji faktor-faktor yang mempengaruhi potensi individu peternak sapi Bali, dan untuk mengetahui potensi individu peternak dalam pengembangan sapi Bali di Kecamatan Taniwel Kabupaten Seram Bagian Barat.

\section{BAHAN DAN METODE}

Penelitian ini dilaksanakan selama dua bulan berlokasi di Kecamatan Taniwel Kabupaten Seram Bagian Barat. Dalam penelitian ditetapkan tiga (3) desa sampel berdasarkan penilaian tertentu (purposive sampling) dengan pertimbangan kepemilihan ternak sapi Bali terbanyak berdasarkan survey awal, dan hasilnya diperoleh desa sampel penelitian meliputi Desa Murnaten, Taniwel, dan Lisabata. Responden yang dijadikan sampel penelitian dipilih secara purposive sampling sebanyak 10 peternak dari masingmasing desa sampel berdasarkan kepemilikan sapi Bali terbanyak, sehingga total responden yang dijadikan sampel penelitian sebanyak 30 peternak.

Penelitian dilaksanakan dengan metode survey menggunakan daftar pertanyaan dan pengamatan langsung di lapangan. Data yang diperoleh dalam penelitian ini dibedakan menjadi data primer dan data sekunder. Data primer merupakan data hasil wawancara, sedangkan data sekunder diperoleh dari instansi terkait yang relevan dengan penelitian ini. Variabel yang diamati adalah potensi dasar peternak yang meliputi pengalaman beternak, pendidikan peternak (formal dan nonformal, kemampuan baca tulis), intensitas berkomunikasi, potensi tenaga kerja peternak, potensi penguasaan teknologi peternak, dan potensi penyediaan input produksi peternak.

Data yang diperoleh ditabulasi sesuai dengan kebutuhan dan kemudian dianalisis menggunakan nilai rata-rata dan simpangan baku berdasarkan Sudjana (1988), dan kemudian dilakukan kajian secara 
deskriptif dari masing-masing variabel pengamatan dengan menggunakan rumus (Dirjen Bina Produksi Peternakan, 2003) yaitu :

1. Potensi Dasar Peternak.

$$
T S p d=\sum_{i=1}^{n} V_{i} W_{i}
$$

dimana:

TSpd = total skor potensi dasar peternak;

$\mathrm{V}_{\mathrm{i}} \quad=$ nilai variabel potensi dasar;

$\mathrm{W}_{\mathrm{i}}=$ pembobot (weight) variabel potensi dasar.

\section{Potensi Tenaga Kerja}

$$
\text { PTK }=\left(\mathbf{T L}_{\mathbf{i}}-\mathbf{A T K s}_{\mathbf{i}}\right) / \mathrm{HKP}_{\mathrm{ST}}
$$

dimana:

PTK = potensi tenaga kerja $(\mathrm{ST})$;

$\mathrm{TL}=$ tenaga kerja tersedia (total labor) $(\mathrm{HKP}) /$ periode;

ATKs = alokasi tenaga kerja saat ini (HKP)/periode; $\mathrm{HKP}_{\mathrm{ST}}=$ kebutuhan tenaga kerja/ST/periode.
3. Potensi Penggunaan Teknologi

$$
T S t=\sum_{i=1}^{n} b_{i} n_{i}
$$

Dimana:

$\mathrm{TSt}=$ total skor potensi penguasaan teknologi peternak;

$\mathrm{B}_{\mathrm{i}}=$ bobot masing-masing variabel penentu penguasaan teknologi;

$\mathrm{N}_{\mathrm{i}}=$ nilai setiap variabel penguasaan teknologi masing-masing peternak.

\section{Potensi Penyediaan Input Produksi}

KPPTk $=\left(\mathbf{K T k}_{\mathbf{i}}-\mathbf{T S s}_{\mathbf{i}}\right)$
dimana;
KPPTk = $\begin{aligned} & \text { nilai peningkatan ternak berdasarkan } \\ & \text { kandang tersedia }(\mathrm{ST})\end{aligned}$
KTk $=$
kapasitas tampung kandang $(\mathrm{ST}) ;$
$=$ ternak yang dimiliki saat ini $(\mathrm{ST})$.

Tabel 1. Skor Potensi Dasar Peternak dalam Pengembangan Sapi Bali di Kecamatan Taniwel

\begin{tabular}{lccr}
\hline \multicolumn{1}{c}{ Potensi Dasar } & Skor Terendah & Skor Tertinggi & Perolehan Skor \\
\hline Pengalaman beternak & 2,5 & 25 & 20,4 \\
Pendidikan formal & 4,5 & 42,5 & 26,9 \\
Pendidikan non formal & 0 & 37,5 & 1,3 \\
Kemampuan membaca dan menulis & 18,75 & 37,5 & 37,5 \\
Intensitas berkomunikasi & 4 & 20 & 8,8 \\
\hline & Total Skor Potensi Dasar Peternak & & 94,9
\end{tabular}

\section{HASIL DAN PEMBAHASAN}

\section{Potensi Dasar}

Peternak merupakan salah satu faktor yang memegang peranan penting dalam usaha peternakan. Pengalaman beternak, tingkat pendidikan formal maupun non formal, kemampuan membaca dan menulis, serta intensitas berkomunikasi merupakan bagian dari potensi dasar seorang peternak yang sangat berpengaruh terhadap pelaksanaan usaha peternakan (Sodiq, 2011 ; Prawira dkk., 2015). Skor potensi dasar peternak dalam pengembangan sapi Bali di kecamatan Taniwel disajikan pada Tabel 1.

Data pengalaman beternak yang diperoleh dari penelitian ini adalah bahwa sebanyak 43,3\% responden memiliki pengalaman usaha 6 sampai 10 tahun, dan sebanyak 56,3\% responden memiliki pengalaman lebih dari 10 (sepuluh) tahun, sedangkan rata-rata skor yang dimiliki menyangkut pengalaman beternak adalah sebesar 20,4 yang menunjukkan bahwa pengalaman beternak yang dimiliki peternak Sapi Bali di Kecamatan Taniwel Kabupaten seram Bagian Barat dikategorikan tinggi atau peternak berpengalaman tinggi. Tingginya pengalaman beternak sapi Bali disebabkan karena usaha peternakan sapi Bali sudah lama dijalani oleh peternak dan oleh sebagian peternak sudah merupakan kegiatan yang telah dilakukan semenjak dari orang tuanya dan diturunkan sebagai warisan bagi mereka. Meskipun pengalaman beternak sudah dikategorikan tinggi namun bagi peternak usaha pengembangan dan poemeliharaan sapi Bali di Kecamatan Taniwel umumnya masih diusahakan secara tradisional atau dalam istilah lokal disebut juga dengan sistem "pengembalaan ikat pindah".

Pengalaman beternak merupakan suatu hal yang sangat mendasari seseorang dalam mengembangkan usahanya dan sangat berpengaruh terhadap keberhasilan usaha (Alam, 2013). Peternak yang telah mempunyai pengalaman dalam beternak akan lebih terampil dan cenderung menghasilkan suatu hasil yang lebih baik daripada peternak yang belum berpengalaman. Peternak yang lebih berpengalaman akan lebih cepat menyerap inovasi teknologi dibandingkan dengan peternak yang belum atau kurang berpengalaman (Soekartawi, 2005).

Tingkat pendidikan responden adalah lama pendidikan yang dihitung dari jumlah tahun 
pendidikan formal terakhir yang pernah ditempuh peternak. Hasil penelitian menunjukkan bahwa $100 \%$ responden pernah mengikuti pendidikan formal dengan rincian persentase tingkatan pendidikan peternak adalah sebagai berikut SD sebanyak $16,7 \%$, SMP sebanyak $36,7 \%$, SMA sebanyak $46,7 \%$, sedangkan rata rata skor yang dimiliki peternak menyangkut pendidikan formal adalah sebesar 26,09. Hasil analisis penelitian diperoleh bahwa rata-rata tingkatan pendidikan yang dimiliki peternak adalah tamatan SMA. Dengan demikian hasil ini menunjukkan bahwa tingkat pendidikan peternak Sapi Bali di Kecamatan Taniwel tergolong tinggi. Tingginya tingkat pendidikan peternak Sapi Bali di Kecamatan Taniwel disebabkan karena beberapa faktor yakni tingginya kesadaran peternak akan pentingnya pendidikan, dan telah tersedianya infrastruktur pendidikan di kecamatan Taniwel. Hal ini sesuai dengan pendapat Soekartawi (2005), menyatakan bahwa dalam prakteknya hubungan antara tingkat pendidikan dan tingkat adopsi pertanian adalah berjalan secara tidak langsung, kecuali bagi mereka yang belajar secara spesifik tentang inovasi baru tersebut di sekolah. Tinggi rendahnya pendidikan yang dimiliki oleh peternak tidak menjamin bahwa mereka akan mengembangkan usahanya, sebab tidak ada perbedaan antara jumlah kepemilikan ternak dilihat dari segi pendidikan. Hal ini tidak sesuai dengan pendapat Murwanto (2008), bahwa tingkat pendidikan yang memadai akan berdampak pada peningkatan kinerja dan kemampuan manajemen usaha peternakan yang dijalankan.

Pendidikan non formal adalah pengajaran sistematis yang diorganisir diluar sistem pendidikan formal bagi sekelompok orang untuk memahami keperluan khusus, contohnya penyuluhan peternak (Suhardyono, 1992). Hasil penelitian tentang pendidikan non formal diperoleh bahwa peternak Sapi Bali di Kecamatan Taniwel sebanyak 63,3\% tidak pernah mengikuti pendidikan non formal, dan hanya $36,7 \%$ peternak yang sudah pernah mengikuti pendidikan non formal. Hal ini disebabkan karena petugas penyuluh lapangan serta instansi terkait yang berada di Kecamatan Taniwel belum melaksanakan tugas sebagaimana mestinya.

Kemampuan membaca dan menulis sangat penting artinya bagi peternak dalam mencari informasi baik melalui buku maupun dari berbagai media cetak. Hasil penelitian menunjukkan bahwa $100 \%$ peternak sapi Bali di Kecamatan Taniwel dapat menulis dan membaca dan menulis secara baik.

Komunikasi yang sering dilakukan peternak adalah sebagai berikut 1) komunikasi antara peternak satu dengan yang lain dalam rangka menukar informasi berupa pengalaman-pegalaman dalam melakukan usaha peternakan Sapi Bali, dan 2) komunikasi melalui media cetak dan elektronik. Hasil penelitian menunjukkan bahwa sebesar $100 \%$ peternak Sapi Bali di Kecamatan Taniwel hanya dapat melakukan intensitas komunikasi antar peternak dengan frekuensi kurang dari satu kali per minggu, sedangkan intensitas komunikasi melalui media cetak dan elektronik belum dapat digunakan peternak secara baik. Rendahnya intensitas komunikasi yang dilakukan oleh peternak disebabkan karena beberapa faktor sebagai berikut : 1) kurangnya pengetahuan peternak tentang perkembangan teknologi peternakan sehingga peternak tidak melakukan komunikasi dengan sesama peternak secara baik, 2) tidak tersedianya fasilitas pendukung media cetak (surat kabar, majalah, dan media lain) yang dapat diperoleh peternak dan untuk media cetak sudah tersedia namun belum semua peternak sapi Bali memiliki fasilitas tersebut.

Hasil penelitian yang diperoleh menunjukkan bahwa total skor potensi dasar peternak individu dalam pengembangan sapi Bali di Kecamatan Taniwel adalah sebesar 94,16. Skor potensi dasar ini jika dibandingkan dengan acuan yang digunakan dalam penelitian ini dimana skor untuk kategori rendah 25,25 sampai 63,08, sedang 63,08 sampai 100,92, dan tinggi lebih dari 100,92, maka potensi dasar individu peternak sapi Bali di Kecamatan Taniwel dikategorikan dalam kategori sedang. Hal ini disebabkan masih rendahnya tingkat pendidikan non formal dan intesitas komunikasi yang dimiliki oleh peternak.

Tabel 2. Potensi Tenaga Kerja Peternak dalam Pengembangan Sapi Bali di Kecamatan Taniwel

\begin{tabular}{rcccc}
\hline Potensi & Skor terendah & Skor Sedang & Skor Tinggi & Perolehan Skor \\
\hline Tenaga kerja & $5-11,66$ & $11,66-18,34$ & 18,35 & 6,17 \\
\hline
\end{tabular}

\section{Potensi Tenaga Kerja}

Potensi tenaga kerja merupakan ketersediaan tenaga kerja peternak dan anggota keluarga yang disetarakan dengan jam kerja produktif. Hasil penelitian menunjukkan bahwa potensi tenaga kerja yang dimiliki peternak berada pada kategori rendah yakni 6,17 (Tabel 2). Rendahnya potensi tenaga kerja yang tersedia bagi usaha peternakan Sapi Bali di Kecamatan Taniwel disebabkan oleh beberapa faktor antara lain: 1) tenaga kerja yang disediakan peternak untuk menjalankan usaha peternakan Sapi Bali adalah tenaga kerja keluarga, 2) jumlah anggota keluarga yang ada cukup banyak namun belum dimanfaatkan secara baik oleh peternak dalam mengelola usaha peternakan, 3) sistem pemeliharaan yang masih berpola tradisional sehingga peternak tidak terlalu memberikan perhatian khusus dalam usahanya. Soekartawi (2005) menyebutkan bahwa analisa 
ketenagakerjaan di bidang pertanian, penggunaan tenaga kerja dinyatakan oleh besarnya curahan tenaga kerja. Curahan tenaga kerja yang dipakai adalah besarnya tenaga kerja efektif yang dipakai. Skala usaha akan mempengaruhi besar kecilnya tenaga kerja yang dibutuhkan dan pula menentukan macam tenaga kerja yang bagaimana yang diperlukan. Selanjutnya disebutkan juga bahwa setiap usaha pertanian yang akan dilaksanakan pasti memerlukan tenaga kerja. Biasanya usaha pertanian skala kecil akan menggunakan tenaga kerja dalam keluarga dan tidak memerlukan tenaga kerja ahli (skilled).

Tabel 3. Potensi Penguasaan Teknologi Peternakan dalam Pengembangan Sapi Bali di Kecamatan Taniwel

\begin{tabular}{lccc}
\hline \multicolumn{1}{c}{ Potensi Penguasaan Teknologi Peternakan } & Skor Terrendah & Skor Tertinggi & Perolehan Skor \\
\hline Memilih Pakan & 3,75 & 18,75 & 3,75 \\
Menyediakan Pakan & 3,75 & 37,5 & 3,75 \\
Pencegahan Penyakit & 3,75 & 37,5 & 1,3 \\
Seleksi & 3,75 & 37,5 & 8,13 \\
\hline
\end{tabular}

Total Penguasaan Teknologi

4,23

\section{Potensi Potensi Penguasaan Teknologi}

Teknologi sebagai penentu potensi peternak dapat meliputi teknologi pakan, pencegahan dan penanggulangan penyakit, dan seleksi ternak. Hasil penelitian menyangkut penguasaan teknologi yang dimiliki peternak sapi Bali di Kecamatan Taniwel dapat dilihat pada Tabel 3. Hasil penelitian menunjukkan bahwa potensi penguasaan teknologi yang dimiliki peternak berada pada kategori rendah yakni 4,23 . Hasil penelitian lapangan menunjukkan bahwa rendahnya penguasaan teknologi peternakan oleh peternak disebabkan oleh 1) peternak belum menguasai teknologi pakan, karena cara pemeliharaan sapi Bali dengan sistem ikat pindah, dimana sapi Bali umumnya dibiarkan merumput tanpa dilakukan seleksi terhadap hijauan yang dikonsumsi ternak, 2) peternak belum dapat melakukan pencegahan dan pengobatan penyakit yang diderita oleh ternak, dan 3) potensi seleksi terhadap induk dan betina belum dapat dilakukan, karena pada pemeliharaan yang diterapkan masih berpola tradisional sehingga perkawinan ternak dibiarkan terjadi secara alami. Rendahnya tingkat penguasaan teknologi oleh peternak disebabkan karena rendahnya tingkat pendidikan peternak sehingga mempengaruhi tingkat pengetahuan peternak tentang sistem peternakan yang baik.

Tabel 4. Potensi Penyediaan Input Peternakan dalam Pengembangan Sapi Bali di Kecamatan Taniwel

\begin{tabular}{lccc}
\hline \multicolumn{1}{c}{ Variabel Potensi Penyediaan Input } & Skor Tertendah & Skor Tertinggi & Perolehan Skor \\
\hline Ketersediaan Kandang & 3 & 5 & 3 \\
Pemilikan Ternak & 3 & 25 & 10 \\
Penyedian Modal & 3 & 25 & 3 \\
\hline \multicolumn{2}{c}{ Total Penyediaan Input } & & 16 \\
\hline
\end{tabular}

\section{Potensi Penyediaan Input Produksi}

Potensi penyediaan input produksi ternak ditentukan oleh kemampuan seluruh anggota peternak dalam menyediakan input produksi berupa pemilikan kandang, kepemilikan ternak dan kemampuan menyediakan uang tunai untuk membiayai kegiatan peternakan dan pengembangan usaha sapi Bali. Pengkategorian potensi penyediaan input dalam usaha peternakan Sapi Bali adalah sebagai berikut : kategori rendah nilai skornya berkisar antara 13 sampai 30,33 ; kategori sedang 30,34 sampai 47,66 ; dan kategori tinggi skornya berkisar antara 47,67 sampai 65 . Hasil penelitian mengenai potensi penyediaan input peternakan sapi Bali di Kecamatan Taniwel dapat dilihat pada Tabel 4.
Hasil penelitian menunjukkan bahwa potensi penyediaan input peternak berada pada kategori rendah dengan skor sebesar 16. Berdasarkan hasil pengamatan langsung di lapangan ditemukan bahwa semua peternakan sapi Bali di Kecamatan Taniwel tidak memiliki kandang, dimana sistem pemeliharaan masih menggunakan sistem ikat pindah tanpa memiliki kandang, bahkan ada sebagian peternak yang membiarkan ternaknya bebas tanpa menggunakan tali untuk kegiatan ikat pindah. Hal lainnya adalah ratarata kepemilikan ternak oleh peternak hanya sebesar 7 satuan ternak. Dalam hal penyediaan modal oleh peternak bagi pengembangan usaha sapi Bali maka hasil penelitian menunjukkan bahwa peternak belum dapat menyediakan uang tunai sebagai modal dalam mengembangkan usahanya. Rendahnya nilai kategori 
penyediaan input peternak disebabkan oleh rendahnya nilai kandang karena peternak tidak memiliki kandang bagi ternaknya serta peternak tidak menyediakan modal berupa uang tunai bagi pengembangan usaha peternakan mereka (Indrayani dkk., 2012 ; Putra dkk., 2018).

Tabel 5. Skor Akhir Potensi Individu Peternak dalam Pengembangan Sapi Bali di Kecamatan Taniwel

\begin{tabular}{lccc}
\hline \multicolumn{1}{c}{ Potensi Individu Peternak } & Skor & Pembobot & Perolehan Skor \\
\hline Potensi Dasar & 94,9 & 3 & 284,7 \\
Tenaga Kerja & 6,17 & 4,5 & 27,77 \\
Penguasaan Teknologi & 4,23 & 4 & 16,92 \\
Penyediaan Input & 16 & 5 & 80 \\
\hline & Total Skor Akhir Potensi Individu Peternak & 409,39 \\
\hline
\end{tabular}

Potensi peternak individu dinilai dari penjumlahan variabel potensi peternak yang meliputi potensi dasar, potensi tenaga kerja, penguasaan teknologi, dan kemampuan menyediakan input produksi. Masing-masing komponen diberi pembobot sesuai dengan kontribusinya terhadap pengembangan usaha ternak, hasilnya seperti tertera pada Tabel 5. Pengkategorian skor akhir potensi individu peternak dalam pengembangan usaha peternakan sapi Bali dapat dijabarkan sebagai berikut : kategori rendah 155,75 - 436,90, kategori sedang 436,91 - 718,05, dan kategori tinggi adalah 718,06 - 999,22. Hasil penelitian menunjukkan bahwa skor akhir potensi peternak dalam pengembangan sapi Bali di Kecamatan Taniwel masuk dalam kategori rendah dengan skor sebesar 409,39.

\section{SIMPULAN}

Dari hasil penelitian disimpulkan bahwa skor potensi dasar peternak sebesar 94,16, skor potensi tenaga kerja yang dimiliki peternak yaitu sebesar 6,17 berada pada kategori rendah, potensi penguasaan teknologi yang dimiliki peternak berada pada kategori rendah yakni dengan skor sebesar 4,23, dan skor potensi penyediaan input oleh peternak adalah sebesar 16 berada pada kategori rendah. Hasil penelitian menunjukkan bahwa skor akhir potensi peternak dalam pengembangan sapi Bali di Kecamatan Taniwel masuk dalam kategori rendah dengan skor sebesar 409,39.

\section{DAFTAR PUSTAKA}

Alam, A. 2013. Curahan waktu kerja keluarga pada usaha peternakan kambing di Kecamatan Leihitu Kabupaten Maluku Tengah. Agrinimal Jurnal Ilmu Ternak dan Tanaman. 3(2): 51-55.

Arfiani, A. M. Fuah, Salundik, \& B. P. Purwanto. 2015. Motivasi dan Partisipasi Peternak dalam Pengembangan Ternak Kerbau di Kabupaten Pandeglang (Studi Kasus: Desa Cibarani Kecamatan Cisata). Jurnal Sains Terapan. 5(1): $1-7$.
Ariningsih, E. 2014. Kinerja Kebijakan Swasembada Daging Sapi Nasional. Forum Penelitian Agro Ekonomi. 32(2): 137 - 156.

[BPS] Badan Pusat Statistik Kabupaten Seram Bagian Barat. 2018. Kecamatan Taniwel Dalam Angka Tahun 2018. Piru: BPS Kabupaten Seram Bagian Barat.

[Dirjen] Direktorat Jenderal Bina Produksi Peternakan. 2003. Pedoman Analisis Potensi Peternak. Jakarta: Departemen Pertanian Republik Indonesia.

Diwyanto, K., \& A. Priyanti. 2008. Keberhasilan Pemanfaatan Sapi Bali Berbasis Pakan Lokal Dalam Pengembangan Usaha Sapi Potong Di Indonesia. Wartazoa. 18(1): 34-45.

Indrayani, I., R. Nurmalina, \& A. Fariyanti. 2012. Analisis Efisiensi Teknis Usaha Penggemukan Sapi Potong di Kabupaten Agam Provinsi Sumatera Barat. Jurnal Peternakan Indonesia. 14(1): 286-296.

Listiana, I. 2010. Faktor - faktor yang Berpengaruh Terhadap Keberhasilan Kemitraan Penggemukan Sapi Potong Antara PT. Great Giant Livestock Company (GGLC) dan Peternak Sapi Di Kabupaten Lampung Tengah. [Tesis]. Surakarta: Program Pasca Sarjana Universitas Sebelas Maret.

Murwanto, A.G. 2008. Karakteristik Peternak dan Tingkat Masukan Teknologi Peternakan Sapi Potong di Lembah Prafi Kabupaten Manokwari. Jurnal Ilmu Peternakan. 3(1): 8 15.

Prawira, H. Y., Muhtarudin, \& R. Sutrisna. 2015. Potensi Pengembangan Peternakan Sapi Potong Di Kecamatan Tanjung Bintang Kabupaten Lampung Selatan. Jurnal Ilmiah Peternakan Terpadu. 3(4): 250-255.

Putra, F. A. I. A., N. Hidayat, \& T. Afirianto. 2018. Penentuan Kelayakan Kandang Sapi 
Menggunakan Analytic Hierarcy ProcessWeighted (AHP-WP) [Studi Kasus UPT Pembibitan Ternak Dan Hijauan Makanan Ternak Singosari]. Jurnal Pengembangan Teknologi Informasi dan Ilmu Komputer. 2(10): 4213-4220.

Rajab. 2013. Dinamika Populasi Sapi Potong Di Kabupaten Raja Ampat. Agrinimal Jurnal Ilmu Ternak dan Tanaman. 3(1): 30-34.

Sodiq, A. 2011. Analisis Kawasan Usaha Pengembangbiakan dan Penggemukan Sapi Potong Berbasis Sumberdaya Lokal Pedesaan untuk Program Nasional Percepatan Pencapaian
Swasembada Daging Sapi. Agripet. 11(1): 2229.

Soekartawi. 2005. Agribisnis Teori dan Aplikasinya. Jakarta: PT Raja Grafindo Persada.

Sudjana, N. 1988. Tuntunan Peyusunan Karya Ilmiah. Bandung: Penerbit Sinar Baru.

Suhardyono, L. 1992. Penyuluhan Pertanian. Edisi ke2. Jakarta: Penerbit Erlangga.

Suroso, K. S., \& Nurhasan. 2014. Pengaruh Potensi Peternak dalam Pengembangan Sapi Potong Di Kecamatan Damsol Kabupaten Donggala. Buana Sains. 14(1): 11-20.

Available online at journal homepage: http://ojs3.unpatti.ac.id/index.php/agrinimal 